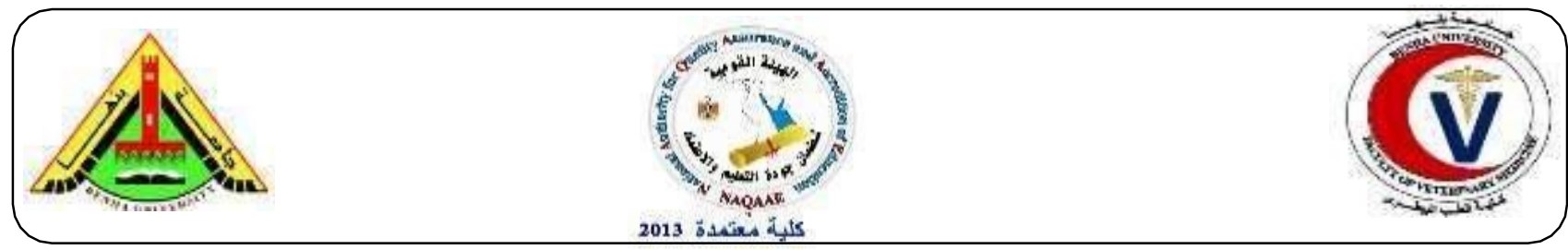

\title{
Spirulina platensis and alpha lipoic acid are protective against deleterious effects of aspartame on the liver and kidneys of rabbits
}

\author{
Samy A. Hussein ${ }^{1}$; Yakout A. Al-Senosy'; Mahamoud.M.Arafa ${ }^{2}$; and Hamam A. Ebead 2* \\ ${ }^{1}$ Department of Biochemistry, Faculty of Vet. Med., Benha University, Egypt. \\ ${ }^{2}$ Department of Biochemistry and food deficiency, Animal Health Research Institute, Agriculture Research Center, \\ Dokki, Giza, Egypt. \\ * Corresponding author: Hamam A. Ebead e-mail: hamamattiya@yahoo.com
}

\section{A BSTRACT}

Spirulina and alpha lipoic acid are the most important antioxidants. The purpose of this study was to explore the adverse effect of (Aspartame) and the protective role of alpha lipoic acid and spirulina in alleviating the deleterious effects of aspartame on the liver and rabbit kidneys. Forty two Rabbits were classified into seven equal groups. Group I: (Control group) received no drugs. Group II: rabbits administered with alpha-lipoic acid $(100 \mathrm{mg} / \mathrm{kg}$ b. wt/day). Group III: rabbits received spirulina platensis (1500 mg/kg b. wt/day). Group IV: rabbits received aspartame ( $250 \mathrm{mg} / \mathrm{kg}$. b. wt/day). Group V: rabbits received aspartame $(250 \mathrm{mg} \mathrm{mg} / \mathrm{kg} \mathrm{b}$. wt) and treated with alpha- lipoic acid (100 mg/kg b. wt). Group VI: rabbits received aspartame $(250 \mathrm{mg} \mathrm{mg} / \mathrm{kg} \mathrm{b} . \mathrm{wt})$ and treated with spirulina $(1500 \mathrm{mg} / \mathrm{kg} \mathrm{b}$. wt). Group VII: rabbits received aspartame $(250 \mathrm{mg} \mathrm{mg} / \mathrm{kg} \mathrm{b.wt})$ and treated daily with alpha- lipoic acid $(100 \mathrm{mg} / \mathrm{kg} \mathrm{b}$. wt) and spirulina $(1500 \mathrm{mg} / \mathrm{kg} \mathrm{b}$. wt) for 8 weeks. Blood samples for serum separation were collected once from all animal groups after eight weeks of experiment. The results revealed a significant increase in serum liver marker enzymes (ALT), (AST), (ALP), kidny function tests (urea, creatinine, uric acid) and lipid profile (total cholesterol and triacylglycerols) and total protein concentration with a significant reduction in serum albumin in aspartame- administrated group. Coadministration of spirulina and alpha lipoic acid with aspartame treated rabbits ameliorate aspartame dangerous effects as revealed by a significant enhancement in all previous biochemical parameters to its normal ranges. These results suggested that, the antioxidant and anti-inflammatory activity of spirulina and alpha lipoic acid could curtail liver impairment and enhanced the harmful impact of aspartame on rabbits liver and kidney.

Key words: Aspartame, Spirulina platensis, alpha-lipoic acid, Hepatorenal function, Rabbits.

(http://www.bvmj.bu.edu.eg)

BVMJ-36(2): 274-281, 2019)

\section{INTRODUCTION}

Aspartame (ASP) is a dietary low-calorie artificial sweetener and is widespread used over the last 30 years. ASP is found in more than 6000 products, including yoghurt, soft drinks, candy, chewing gum, tabletop sweeteners fruit juices, jellies, gelatins and drugs such as vitamins and sugar-free cough drops (Choudhary and Devi, 2014). ASP represents a higher source of oxidative stress since it is rapidly metabolized into methanol, phenyl- alanine and aspartic acid. Methanol is further metabolized by oxidation to formaldehyde and then to formate. These processes are accompanied by formation of superoxide anion and hydrogen peroxide which cause harmful effects of acute intoxication in many organs especially on liver functions. ASP consumption, the concentration of its metabolites increases in the blood (Humphries et al., 2008). After tissue damage, some of the enzymes find their way 
into the serum leaking through membranes with altered permeability. Activity determinations of serum enzymes aspartate aminotransferase (AST), alanine aminotransferase (ALT), lactate dehydrogenase (LDH) and $\gamma$-glutamyl transpeptidase $(\gamma \mathrm{GT}))$ are a valuable tool in clinical diagnosis. The measurement of these enzymes' activities in tissues and body fluids can be used to estimate the degree of toxic-ity of a chemical compound on an organ/tissues (Vijan, 2010; Abdhilash et al., 2011). This is in accordance with (Amin et al., 2016) who notice marked elevation in creatinine and urea due to the aspartame toxicity. As the kidney has an important role in excretion of various waste metabolites from the body, studies on nephrotoxic effect of artificial sweeteners, especially aspartame, have increased (Martins and Azoubel, 2007). Additionally, sugarsweetened beverages (SSBs) are any beverage with added sugar, which includes soft drinks (soda), fruit drinks, iced tea, and energy and vitamin water drinks. The primary cause of gout is hyperuricemia due to excess urate production or impaired renal excretion of uric acid. (Terkeltaub, 2003).

Spurulina has stimulatory effect on the physical stamina and acts as liver detoxifier, bowel cleanser and as catalyst for the absorption of essential elements. (Hyo-Jin et al., 2006). Spirulina strongly induces antioxidant enzyme activity, helps to prevent lipid peroxidation and DNA damage and scavenges free radicals.

Alpha lipoic acid acts as coenzyme of pyruvate and It protects against oxidative stress both in peripheral tissues and central nervous system (Winiarska et al., 2008). Also, alpha lipoic acid exerts strong oxidative protection in the liver and kidney against free radical induced cellular damage (Morakinyo et al., 2012). This study was designed to investigated the adverse effect of artificial sweetener (aspartame) on some serum biochemical constituents of liver and kidney function and the possible protective role of spirulina and alpha lipoic acid to ameliorate these deleterious effects which may produce from aspartame administration in rabbits.

\section{MATERIAL AND METHODS}

\subsection{Experimental Animals.}

Forty two white male New-Zealand Rabbits of 4-6 weeks old age and average body weight
800-1200 $\mathrm{g}$ were used in the experimental investigation of this study. Rabbits were obtained from Laboratory Animals Research Center Faculty of Veterinary Medicine, Benha University. Rabbits were housed in separated metal cages (6 per cage) and they were kept on a well balanced ration and fresh clean drinking water ad-libitum. Rabbits were kept at a constant environmental and nutritional condition throughout the whole period of experiment. All rabbits were left for 15 days for acclimatization before the start of the experiment.

\subsection{Chemicals and antioxidants}

The chemicals and antioxidants used in the present study were:

\section{2.a. Aspartame:}

Aspartame was purchased from Al-Ameriya pharma company, Egypt. Aspartame was manufacture in the form of tablets each one tablet contains $20 \mathrm{mg}$ of aspartame.

\section{2.b. Spirulina platensis}

Spirulina microalgae blue green powder was obtained from Cairo National Research Center Dokki-Egypt.

Preparation and dosage of Spirulina: Spirulina was freshly prepared by dissolved in distilled water and administered orally using stomach tube in a daily dose of $1500 \mathrm{mg} / \mathrm{kg}$ body weight (Colla, et al.,2008).

2.2.c. Alpha lipoic acid (thioctic acid).

Synonyms: thioctic acid, 6, 8-dithiooctanoic acid, 1, 2dithiolane-3-pantanoic acid. Alpha lipoic acid (Thiotacid) ${ }^{\circledR}$ tablets was manufactured by Eva pharma Egypt.

Note: The content of each tablet $600 \mathrm{mg}$ of $\alpha$ Lipoic acid was dissolved in propylene glycol which manufactured by El-Nasr Pharmaceutical Chemicals Co. Abu Zaabal, Egypt.

Dosage: DL- $\alpha$-Lipoic acid was given orally in a daily dose of $100 \mathrm{mg} / \mathrm{kg}$ body weight (Şehirli et al., 2008).

\subsection{Experimental design}

After acclimatization to the laboratory conditions, the rabbits were randomly divided into seven equal groups, each one consisting of sixanimals placed in individual cages and classified as follows:

Group I: (Control group) received no drugs.

Group II: rabbits administered with alpha-lipoic acid (100 mg/kg b.wt/day) 
Group III: rabbits received spirulina platensis (1500 mg/kg b. wt/day).

Group IV: rabbits received aspartame (250 $\mathrm{mg} / \mathrm{kg}$. b. wt/day). Group V: rabbits received aspartame $(250 \mathrm{mg} \mathrm{mg} / \mathrm{kg} \mathrm{b}$. wt) and treated with alpha- lipoic acid ( $100 \mathrm{mg} / \mathrm{kg} \mathrm{b}$. wt).

Group VI: rabbits received aspartame $(250 \mathrm{mg}$ $\mathrm{mg} / \mathrm{kg} \mathrm{b.wt}$ ) and treated with spirulina platensis (1500 mg/kg b. wt).

Group VII: rabbits received aspartame (250 mg $\mathrm{mg} / \mathrm{kg}$ b.wt) and treated daily with alpha- lipoic acid $(100 \mathrm{mg} / \mathrm{kg} \mathrm{b}$. wt) and spirulina platensis $(1500 \mathrm{mg} / \mathrm{kg} \mathrm{b}$. wt) for 8 weeks.

\subsection{Sampling}

\subsubsection{Blood samples}

Twenty-four hours after the last dose of alphalipoic acid and spirulina platensis administration, blood samples were collected by vein puncture of the marginal ear vein from all animal groups in dry, clean tubes and allowed to clot for 30 minutes and serum was separated by centrifugation at 3000 r.p.m for 15 minutes. The clean, clear serum was processed directly for determination of AST, ALT and ALP activities, then kept in a deep freeze at $20^{\circ} \mathrm{C}$ until used for subsequent biochemical analysis. All sera were used for determination of the following parameters: Total protein, albumin, urea, creatinine, uric acid, total cholesterol and triacylglycerols.

\subsection{Biochemical analysis.}

Serum (ALT and AST), ALP, total protein, albumin ,urea, creatinine, uric acid, total cholesterol, triacylglycerol were determined according to the method described by Reitman, and. Frankel, (1957). Tietz et al., (1983). Gomal et al.,(1949); Doumas et al.,(1971); Young, (1990); Tietz,.,(1986)., Trivedi,..(1978)., Caraway and Watts (1987), Todd and Henry (1984); respectively.

\subsection{Statistical analysis}

The results were expressed as mean \pm SE using
SPSS software program version 16 (SPSSC) Inc., USA). The data were analyzed using oneway ANOVA to determine the statistical significance of differences among groups. Duncan's test was used for making a multiple comparison among the groups for testing the inter-grouping homogeneity. Values were considered statistically significant when $\mathrm{p}<0.05$.

\section{RESULTS}

The obtained results in table (1) revealed that oral aspartame administration to rabbits for 8 weeks exhibit a significant increase in serum ALT, AST, ALP activities and total protein concentration with marked reduction in serum albumin level when compared with control group. On the other hand, coadministration of spirulina and alpha lipoic acid with aspartame treated rabbits for 8 weeks caused significant decrease in serum ALT, AST, ALP activities and total protein concentration and markedly increased serum albumin level when compared to aspartame treated group. Additionally, no significant changes were noticed in all pervious parameters among the three groups (control normal(G1), alpha- lipoic acid (GII) and spirulina (GIII) administered rabbits.

The obtained data table (2) demonstrated that, oral aspartame administration to rabbits for 8 weeks induced a significant increase in serum urea, creatinine, uric acid in addition to total cholesterol and triacylglycerol concentrations when compared with control group. Meanwhile, spirulina and alpha-lipoic acid administration with aspartame treated rabbits for 8 weeks exhibit a significant decrease in serum kidney function tests (urea ,creatinine, uric acid) as well as total cholesterol and triacylglycerol concentrations when compared to aspartame administered group. Furthermore, no significant changes were noticed in all pervious parameters among the three groups (control normal (G1), alpha-lipoic acid (GII) and spirulina (GIII) administered rabbits 
Table (1): Effect of Spirulina or/and alpha-Lipoic acid on serum liver marker enzymes activities, total protein and albumin concentrations in aspartame administered male rabbits.

\begin{tabular}{lccccc}
\hline \multicolumn{1}{c}{ Animal groups } & $\begin{array}{c}\text { ALT } \\
(\text { IU/L) }\end{array}$ & $\begin{array}{c}\text { AST } \\
(\mathrm{IU} / \mathrm{L})\end{array}$ & $\begin{array}{c}\text { ALP } \\
(\mathrm{IU} / \mathrm{L})\end{array}$ & $\begin{array}{c}\text { Total protein } \\
(\mathrm{g} / \mathrm{dl})\end{array}$ & $\begin{array}{c}\text { Albumin } \\
(\mathrm{g} / \mathrm{dl})\end{array}$ \\
\hline G I:Control & $14 \pm 0.7^{\mathrm{d}}$ & $16.4 \pm 1.106^{\mathrm{e}}$ & $50.6 \pm 1.28^{\mathrm{d}}$ & $7.06 \pm 0.06^{\mathrm{c}}$ & $3.86 \pm 0.13^{\mathrm{d}}$ \\
G II:L.A & $12.8 \pm 0.37^{\mathrm{d}}$ & $17 \pm 0.54^{\mathrm{e}}$ & $46.6 \pm 1.07^{\mathrm{d}}$ & $7.26 \pm 0.07^{\mathrm{bc}}$ & $3.92 \pm 0.37^{\mathrm{ab}}$ \\
G III:Spirulina & $13.6 \pm 0.5^{\mathrm{d}}$ & $18 \pm 0.58^{\mathrm{e}}$ & $49.75 \pm 2.01^{\mathrm{d}}$ & $5.8 \pm 1.27^{\mathrm{c}}$ & $4.04 \pm 0.13^{\mathrm{a}}$ \\
G IV:Aspartame & $48.8 \pm 3.1^{\mathrm{a}}$ & $76.8 \pm 1.52^{\mathrm{a}}$ & $124 \pm 3.68^{\mathrm{a}}$ & $8.9 \pm 0.12^{\mathrm{a}}$ & $2.76 \pm 0.16^{\mathrm{c}}$ \\
GV:Asp+L.A & $34 \pm 1.14^{\mathrm{b}}$ & $34 \pm 1.14^{\mathrm{b}}$ & $65.4 \pm 2.48^{\mathrm{c}}$ & $7.42 \pm 0.03^{\mathrm{b}}$ & $3.64 \pm 0.09^{\mathrm{b}}$ \\
GVI:Asp+Spir & $29.6 \pm 0.24^{\mathrm{c}}$ & $29.6 \pm 0.24^{\mathrm{c}}$ & $88.2 \pm 2.49^{\mathrm{b}}$ & $7.1 \pm 0.04^{\mathrm{bc}}$ & $3.62 \pm 0.03^{\mathrm{c}}$ \\
G II:Asp+L.A+Spir & $21 \pm 0.63^{\mathrm{d}}$ & $21 \pm 0.63^{\mathrm{d}}$ & $47.6 \pm 1.28^{\mathrm{cd}}$ & $6.98 \pm 0.26^{\mathrm{c}}$ & $4.52 \pm 0.59^{\mathrm{a}}$ \\
\hline
\end{tabular}

Data are presented as (Mean $\pm \mathrm{SE}$ ). $\mathrm{SE}=$ Standard error. Mean values with different superscript letters in the same column are significantly different at $(\mathrm{P} \leq 0.05)$.

Table (2): Effect of Spirulina or/and alpha-Lipoic acid on serum lipid profile (total cholesterol, triacylglycerol) and kidney function tests (urea, creatinine, uric acid ) concentrations in aspartame administered male rabbits.

\begin{tabular}{lccccc}
\hline \multicolumn{1}{c}{ Animal groups } & $\begin{array}{c}\text { Total Cholesterol } \\
(\mathrm{mg} / \mathrm{dl})\end{array}$ & $\begin{array}{c}\text { Triacylglycerols } \\
(\mathrm{mg} / \mathrm{dl})\end{array}$ & $\begin{array}{c}\text { Urea } \\
(\mathrm{mg} / \mathrm{dl})\end{array}$ & $\begin{array}{c}\text { creatinine } \\
(\mathrm{mg} / \mathrm{dl})\end{array}$ & $\begin{array}{c}\text { Uric acid } \\
(\mathrm{mg} / \mathrm{dl})\end{array}$ \\
\hline G I: Control & $103 \pm 4.91^{\mathrm{d}}$ & $50 \pm 1.58^{\mathrm{de}}$ & $18 \pm 1.14^{\mathrm{cd}}$ & $0.66 \pm 0.08^{\mathrm{bcd}}$ & $2.87 \pm 0.13^{\mathrm{c}}$ \\
G II: L.A & $92 \pm 2.07^{\mathrm{e}}$ & $45 \pm 1.58^{\mathrm{e}}$ & $16.6 \pm 0.50^{\mathrm{cd}}$ & $0.64 \pm 0.01^{\mathrm{cd}}$ & $3.24 \pm 0.08^{\mathrm{bc}}$ \\
G III: Spirulina & $95.6 \pm 2.50^{\mathrm{de}}$ & $47 \pm 2.00^{\mathrm{e}}$ & $15.2 \pm 0.80^{\mathrm{d}}$ & $0.56 \pm 0.04^{\mathrm{d}}$ & $2.94 \pm 0.04^{\mathrm{c}}$ \\
G IV: Aspartame & $180 \pm 1.37^{\mathrm{a}}$ & $86 \pm 1.87^{\mathrm{a}}$ & $48.4 \pm 2.97^{\mathrm{a}}$ & $1.81 \pm 0.13^{\mathrm{a}}$ & $7.02 \pm 0.32^{\mathrm{a}}$ \\
GV: Asp+L.A & $121.2 \pm 1.74^{\mathrm{c}}$ & $58 \pm 1.22^{\mathrm{c}}$ & $24.2 \pm 0.05^{\mathrm{c}}$ & $0.85 \pm 0.2^{\mathrm{b}}$ & $3.26 \pm 0.10^{\mathrm{b}}$ \\
GVI: Asp+Spir & $139.4 \pm 4.14^{\mathrm{b}}$ & $66 \pm 1.87^{\mathrm{b}}$ & $22.2 \pm 0.66^{\mathrm{c}}$ & $0.82 \pm 0.02^{\mathrm{bc}}$ & $3.44 \pm 0.11^{\mathrm{b}}$ \\
GII: Asp+L.A+Spir & $113.4 \pm 1.72^{\mathrm{c}}$ & $52 \pm 2^{\mathrm{cd}}$ & $20.6 \pm 0.6^{\mathrm{bc}}$ & $0.8 \pm 0.03^{\mathrm{bc}}$ & $3.08 \pm 0.03^{\mathrm{bc}}$ \\
\hline
\end{tabular}

Data are presented as (Mean \pm SE). SE $=$ Standard error. Mean values with different superscript letters in the same column are significantly different at $(\mathrm{P} \leq 0.05)$.

\section{4-DISCUSSION}

Aspartame (E 951) is the most commonly used non-nutritive artificial sweeteners in over 100 countries in more than 6000 products harmacidical product \&feed, drugs and including soft drinks, fruit juice, baked goods, chewing gum, candy, puddings, canned foods, ice cream, yogurt, table sweeteners and plenty of other foods and beverages (Magnuson, et al., 2007). The present results showed that, treatment with aspartame caused significant elevation in the activities of serum liver marker enzymes (ALT and AST and ALP) as compare to control group. This results agree with Morakinyo et al.,(2012) who showed that administration of aspartame $(100 \mathrm{mg} / \mathrm{kg} \mathrm{b}$. wt) with lipoic acid significantly decreased the value of serum AST, ALT and ALP activities as compared to the control group. However, spurulina and alpha- lipoic acid treatment led to limited decrease in ALT and AST and ALP activities and increase in total protein and albumin relating to aspartame group probably because of the remarkable antioxidant property of spurulina and lipoic acid that drastically attenuated liver tissue damage. The increase in serum ALT, AST activities provides another confirmation for liver injury caused by oxidative stress which induced by aspartame. This results agree with Iyaswamy et al., (2017) who reported that ALT and AST located in the cytosol but escape out from the cell into extracellular fluids and blood flowing due to changes in the permeability of hepatocyte membranes due to increased lipid peroxidation induced by oxidative stress. Also, who exhibits that long-term consumption of aspartame may induce changes on the redox status of liver functions. However, aspartame and its 
metabolite methanol could induce liver damage via the mechanism of apoptosis and bring out hepatotoxicity. The marked regulation of liver enzymes, total protein and albumin after spurulina and lipoic acid treatment may prove that spurulina and lipoic acid conserves the structural integrity of liver against ASP-induced injury through the capacity to ROS scavenger as well as through stimulation of endogenous antioxidant defense system. Aspartame caused elevation total protein. This is indication for liver dysfunctions and treated by spirulina and alpha-lipoic acid resulted in enhancement of protein level nearly to its normal ranges of control group, this indicate the ability of spiurulina and lipoic acid to modulate the liver function. As well as, the results of the present study are in conformid with those reported by Iyaswamy et al., (2017) who demonstrates that long-term consumption of aspartame may induce changes on the redox status of liver functions; however, aspartame and its metabolite methanol could induce liver damage via the mechanism of apoptosis and bring out hepatotoxicity. The marked regulation of liver enzymes, total protein and albumin after rosemary treatment may prove that rosemary conserves the structural integrity of liver against ASP-induced injury through the capacity to ROS scavenger as well as through stimulation of endogenous antioxidant defense system. A significant increase in serum triacylglycerol and total cholesterol concentrations were observed in aspartame treated rabbits group. Similarly, Marko et al.,(2015) display that treatment with ASP caused an increase in the concentrations of serum total cholesterol, LDL-cholesterol and triacylglycerol. Also, Subramanian et al., (2015) shown that, serum total cholesterol, LDL-cholesterol and triacylglycerol were significantly increased. Meanwhile, spirulina and alpha-lipoic acid administration with aspartame treated rabbits for 8 weeks exhibit a significant decrease in serum total cholesterol and triacylglycerol concentrations when compared to aspartame administered group. Likewise, Kurushima et al., (1995) reported that, spurulina platensis caused a marked decrease in the hypercholesterolemia -induced in rabbits. Who added that, spirulina decrease the serum levels of total cholesterol and increase HDL-cholesterol, consequently spirulina act as a protective factor against the development of atherosclerosis. As confirmed with Yang et al., (2008) who reported that supplementation with alpha lipoic acid caused apparent decrease in lipid peroxidation, plasma cholesterol, triglycerides and low density lipoprotein cholesterol concentrations with marked increase in high-density lipoprotein cholesterol level.

In the current study aspartame administration caused significant elevation in serum urea, uric acid and creatinine concentrations.

Correspondingly, Adaramoye and Akanni (2016) show that aspartame administration at three different concentrations $15 \mathrm{mg}, 35 \mathrm{mg}$ and $70 \mathrm{mg} / \mathrm{kg}$ b.wt./day for 9 weeks significantly increased the levels of total cholesterol, triglycerides and low-density lipoprotein, alanine aminotransferase, urea , creatinine and uric acid. This is another indication for liver dysfunctions as high urea levels mean that activities of the urea cycle enzymes increased which increase the capacity of the liver to synthesize urea and this may relate to the increased catabolism than anabolism of proteins. This suggestion was supported by previous studies of Alsoufi, (2017) and Meyburg et al., (2018). Also, the elevated serum levels of urea and creatinine indicate reduced ability of the kidney to eliminate the toxic metabolic substances. Parthasarathy et al., (2006) showed that methanol administration significantly increased serum urea and creatinine levels. Additionally, Maiuolo, et al., (2016) reported that the liver is one of the main organs for endogenous production of uric acid, and it is eliminated by kidney. The balance of uric acid formation and excretion is driven by several enzymatic pathways which regulated by pathophysiological factors as metabolic products and free radical species. Furthermore, hyper-uricemia is independently associated with the severity of liver damage and elevation of liver enzymes, AST and ALT which recorded in the present study. In addition, the elevations of urea and uric acid also reflect the severity of kidney dysfunction. Furthermore, Adaramoye and Akanni (2016) reported that impairment of kidney association with a justly sudden fall in glomerular filtration rate because of methanol. Methanol the metabolite of aspartame that enters the proximal tubular cells, binds to anionic phospholipids and inducing abnormal function and metabolism of intracellular membranes and other organelles, and developed injury in the tubular epithelial cells in kidney. Meanwhile, spirulina and alpha-lipoic acid administration with aspartame treated rabbits 
for 8 weeks exhibit a significant decrease in serum kidney function tests (urea ,creatinine and uric acid) concentrations when compared to aspartame administered group. Spirulina is rich in $\beta$-carotene and the bioavailability is as good as the pure $\beta$-carotene, vitamin $\mathrm{E}$ and vitamin $\mathrm{C}$ and selenium, and spirulina extracts could be effective against free radical induced lipid peroxidation which in turn may lead to cellular transformation (Pal et al., 2010) and also reduced serum urea, creatinine and uric acid concentrations. Alpha lipoic acid exerts strong oxidative protection in the liver and kidney against free radical induced cellular damage (Morakinyo et al., 2012). So, in the current studies usage of natural antioxidants like spirulina as a protective strategy against toxicity induced by aspartame remain more effective than treated with lipoic acid because the antioxidant potential of Spirulina species and protective effects are mediated by phycocyanins, $\beta$-carotene, and other vitamins and minerals contained within Spirulina.

\section{CONCLUSION}

It could be concluded that, the potential ameliorating effect of spirulina and alpha-lipoic acid as powerful antioxidant and antiinflammatory agents in combating free radicalinduced oxidative stress and improved the damaging impact of aspartame on liver and kidney tissues. Therefore, these results confirm the strong antioxidant, anti-inflammatory and cytoprotective effects of spirulina and alphalipoic acid that may alleviate the undesirable and dangerous effects during aspartame exposure.

\section{REFERENCES}

Abhilash, M.; Paul, M.V.S.; Arghese, M.V. V. and Nair, R.H. 2011.Effect of long term intake of aspartame on antioxidant defense status in liver. Food Chem.Toxicol., 49:1203-1207.

Adaramoye, O.A. and O.O. Akanni, 2016. Effects of long-term administration of aspartame on biochemical indices, lipid profile and redox status of cellular system of male rats.Journal of basic and clinical physiology and pharmacology ; 27(1): 29-37.

Al-Qudsi, F.M. and M.M. Al-Hasan, 2019. In utero exposure to commercial artificial sweeteners affects mice development and mammary gland structure. Environmental Science and Pollution Research,; 26(5): 5054-5064.

Alsoufi, M.A., R.A. Aziz, and Z.G. Hussein, 2017.Effect of some artificial sweeteners consumption in biochemical parameters of rats. Curr. Res. Microbiol. Biotechnol,;5: 10951099.

Amin, K.A.; H.M. Al-Muzafar, and A.H. Abd Elsttar, 2016. Effect of sweetener and flavoring agent on oxidative indices, liver and kidney function levels in rats. Indian J. Exp. Biol., 54: 56-63.

Caraway, W.T., Watts, M.B., 1987. Carbohydrates. In Fundamentals of clinical Chemistry. 3rd ed. Philadelphia: WB Saunders; 422-447.

Choudhary, A.K. and R.S. Devi, 2014. Serum biochemical responses under oxidative stress of aspartame in wistar albino rats. Asian Pacific Journal of Tropical Disease,; 4: S403-S410.

Colla, L.M., Muccillo-Baisch, A.L., Costa, J.A.V., 2008. Spirulina platensis Effects on the Levels of Total Cholesterol, HDL and Triacylglycerols in Rabbits Fed with a Hypercholesterolemic Diet. Brazilian Arch Biol and Technol. 2008; 51:405-411.

Doumas, B.T., W.A. Watson, and H.G. Biggs, 1971. Albumin standards and the measurement of serum albumin with bromcresol green. Clinica chimica acta,; 31(1): 87-96.

Gomal, A., C. Bardawill, and M. David, Colorimetric method for total protein determination. J Biol Chemi, 1949; 177: 751.

Humphries, P., Pretorius, E. and E.H. Naud., 2008. Direct and indirect cellular effects of aspartame on the brain. Eur. J. Clin. Nutr.62, 451-462.

Iyaswamy, A., S. K. DurairajanS. G. Shetty "Huanglian-Jie-Du-Tang 2017.Disruption of redox homeostasis in liver function and activation of apoptosis on consumption of aspartame in folate deficient rat model. Journal of 
nutrition \& intermediary metabolism, ; 8: 41-50.

Kurushima, H.; Hayashi, K.; Shingu, T.; Kuga, Y.; Ohtani, H.; Okura, Y.; Tanaka, K.; Yasunobu, Y.; Nomura, K.; Kajiyama, G. 1995.Opposite effects on cholesterol metabolism and their mechanisms induced by dietary oleic acid and palmitic acid in hamsters. Biochimica et Biophysica Acta, v. 1258, 251-256.

Magnuson BA, Burdock GA, Doull J, Kroes RM, Marsh GM, Pariza MW,. 2007. Aspartame: a safety evaluation based on current use levels, regulations, and toxicological and epidemiological studies. Crit Rev Toxicol;37:629-37.

Maiuolo, J., Francesca Oppedisano Santo Gratteri Carolina Muscoli Vincenzo Mollace, 2016. Regulation of uric acid metabolism and excretion. International journal of cardiology, 213: 8-14.

Marko D. P., Milica,G. P., Miloš,M. M., Nataša,Z. D., Branka I. O., Andraš Š. Š.,Zorica S. S. 2015.Effect of aspartame on biochemical and oxidative stress parameters in rat blood. Arch. Biol. Sci., Belgrade 67(2):535545.

Martins, M.R.I. and Azoubel, R., 2007.Effects of aspartame on fetal kidney: a morphometric and stereological study. Int. J. Morphol., 25: 689-694.

Meyburg, J Opladen T, Spiekerkötter U, Schlune A, Schenk JP, Yudkoff M,2018.Human heterologous liver cells transiently improve hyperammonemia and ureagenesis in individuals with severe urea cycle disorders. Journal of inherited metabolic disease,; 41(1): 8190.

Morakinyo,A.O., Oludare, G.O., Anifowose, A.A., Adegoke OA., 2012. Protective effects of alpha lipoic acid on carbon tetrachloride-induced liver and kidney damage in rats. British J. Pharmacol. and Toxicol. (1): 21-28.

Ohkawa, H., N. Ohishi, and K. Yagi, Assay for lipid peroxides in animal tissues by thiobarbituric acid reaction. Analytical biochemistry, 1979; 95(2): 3.51-358.
Pal, R.; Girhepunje, K.; Gevariya, H. and Thirumoorthy, N. 2010: Hepatoprotective activity of Beta vulgaris against $\mathrm{CCl} 4$ induced acute hepatotoxicity in rats. Archives of Applied Science Res 2 (1), 14-18.

Parthasarathy J.N., Ramasundaram S.K., Sundaramahalingam M., Rathinasamy S.D., 2006. Methanol-induced oxidative stress in rat lymphoid organsJournal of Occupational Health, 48 pp. $20-27$,

Reitman, S. and S. 1957. Frankel, Glutamicpyruvate transaminase assay by colorimetric method. American Journal of Clinical Pathology; 28(1): 56-63. 21.

Gomal, A., C. Bardawill, and M. David, Colorimetric method for total protein determination. J Biol Chemi, 1949; 177: 751.

Şehirli, O.; Tatlıdede, E.; Yüksel, M.; Erzik, C.; Cetinel, S.; Yeğen, B.C. and Şener, G., 2008. Antioxidant Effect of AlphaLipoic Acid against Ethanol-Induced Gastric Mucosal Erosion in Rats. 81:173-180.

Stein, Ruediger; Rullkötter, Jürgen; Kalkreuth, Wolfgang; Welte, Dietrich Hugo (1987): Quantity, provenance, and thermal maturity of organic matter at DSDP Holes 95-612 and 95-613.

Subramanian S, Khan HBH, Elumalai N, Lakshmi SYS. , 2015. Hepatoprotective effect of ethanolic extract of whole plant. in rats. Comp Clin Path; 24: 1-7.

Terkeltaub RA. 2003: Clinical practice. Gout. N Engl J Med .Tietz N. W., Rinker A. D., Shaw L. M.,1983.IFCC Methods for the Measurement of Catalytic Concentration of Enzymes, Part 5. IFCC Method for Alkaline Phosphatase. J. Clin. Chem. Clin. Biochem. Toxicol 11, 221-228.

Tietz, N., Textbook of clinical chemistry WB Saunders. Philadelphia, 1986: 1279. 25. Trivedi, R.C., et al., New enzymatic method for serum uric acid at $500 \mathrm{~nm}$. Clinical Chemistry, 1978; 24(11): 1908-1911.

Tietz, N.W., Burtis, C.A., Duncan, P., Ervin, K., Petitclerc, C.J., Rinker, A.D., Shuey, 
D., Zygowicz, E.R., 1983.A reference method for measurement of alkaline phosphatase activity in human serum. Clinical chemistry 29, 751-761.

Todd, J.C.,J.B. Henry., 1984.Clinical Diagnosis and Management by Laboratory Methods. 17th Edn., Saunders Publisher, New York, USA., ISBN-13: 978-0721646572, Pages: 1522.

Torress-Duran, P.V.; Ferreira-Hermosillo, A. and Juarez-Oropeza, M.A. 2007. Antihyperlipemic and antihypertensive effects of Spirulina maxima in an open sample of Mexican population: a preliminary report. Lipids Health Dis., 6: 33-41.

Trivedi, R.C., et al., 1978. New enzymatic method for serum uric acid at $500 \mathrm{~nm}$. Clinical Chemistry; 24(11): 1908-1911.
Vijan, S. ,2010.“Type 2 diabetes”. Ann. Intern. Med.152, 15-31.

Walton, R.G. 1988.The possible role of aspartame in seizure induction. In: Dietary Phenylalanine and Brain Function, 159-162.

Winiarska, K., Malinska, D., Szymanski, K., Dudziak, M.,Bryla, J., 2008.Lipoic acid ameliorates oxidative stress and renal injury in alloxan diabetes rabbits. Bioch.90: 450459.

Yang, R.L., Li,W., Shi,Y.H., Le,G.W., 2008. Lipoic acid prevents high-fat dietinduced dyslipidemia and oxidative stress: a microarray analysis. Nut. 24: $582-588$.

Young, DS. 1990:.Effects of Drugs on Clinical Laboratory Tests. Third Edition: 3: 612. 